\title{
In vitro GROWTH OF ECTOMYCORRHIZAL FUNGI ASSOCIATED WITH Pinus radiata PLANTATIONS IN CHILE
}

\section{CRECIMIENTO in vitro DE HONGOS ECTOMICORRÍCICOS ASOCIADOS CON PLANTACIONES DE Pinus radiata EN CHILE}

\author{
José-Leonardo García-Rodríguez ${ }^{1,4 *}$, Jesús Pérez-Moreno², Darcy Ríos-Leal' ${ }^{1}$ Patricia Saez- \\ Delgado ${ }^{1}$, Cristian Atala-Bianchi ${ }^{3}$, Manuel Sánchez-Olate ${ }^{1}$ and Guillermo Pereira-Cancino ${ }^{1,4}$
}

\begin{abstract}
'Programa de Postgrado en Ciencias Forestales, Facultad de Ciencias Forestales, Universidad de Concepción. Victoria 631, Barrio Universitario, Concepción Región del Biobío, Chile. Tel. (56-41) 22046 79. ²Colegio de Postgraduados, Postgrado en Edafología, Laboratorio de Microbiología, Colegio de Postgraduados, Campus Montecillo. Carretera México-Texcoco km 36.5. 56230, Montecillo, Texcoco, Estado de México Tel. (595) 9520200 Ext. 1276. ${ }^{3}$ Laboratorio de Anatomía y Ecología Funcional de Plantas, Instituto de Biología, Facultad de Ciencias, Pontificia Universidad Católica de Valparaíso, Campus Curauma. Avenida Universidad 330, Valparaíso, Chile. ${ }^{4}$ Laboratorio de Biotecnología de Hongos. Campus Los Ángeles, Universidad de Concepción. Juan Antonio Coloma 0201, Los Ángeles, Chile. Teléfono: (56-43) 2405200.
\end{abstract}

*Corresponding autor (jgarciar@udec.cl)

\section{SUMMARY}

A comparative study of in vitro growth of three species of ectomycorrhizal fungi (ECMF) (Rhizopogon luteolus, Suillus granulatus and Suillus luteus) was performed. Fungal material was collected in adult Pinus radiata plantations. Isolation and purification of the strains were performed on potato-dextroseagar medium and the evaluation of the radial growth rate and the increase in mycelial biomass, under different culture conditions, was performed on the Modified Melin Norkrans growth medium. The effects of temperature $(24,28$ and $\left.32{ }^{\circ} \mathrm{C}\right)$ and $\mathrm{pH}(4.8,5.3,5.8,6.3$ and 6.8$)$ of the growth medium were tested for the three fungal species in two independent assays. The results indicate that the temperature had a significant effect on the radial growth rate (RG) and mycelial biomass increase (MB) in all of the evaluated fungal species. The highest RGR and MBI were recorded in R. luteolus, and the lowest values for these variables were registered in S. luteus. Rhizopogon luteolus had the highest sensitivity to $\mathrm{pH}$ changes. Meanwhile, there was no pattern in S. granulatus and $\mathrm{S}$. luteus growth response under different $\mathrm{pH}$ conditions. When cultivated in vitro, the three studied species of ECMF presented adaptation, exponential, declining and stationary growth phases. The in vitro growth responses recorded in the present study showed the great potential of $R$. luteolus to be used in future programs using mycorrhizal inoculation in the production of Pinus radiata trees in nurseries in Chile.

Index words: Rhizopogon, Suillus, biomass, pure culture, radial growth rate.

\section{RESUMEN}

Se hizo un estudio comparativo del crecimiento in vitro de tres especies de hongos ectomicorrícicos (ECMF) (Rhizopogon luteolus, Suillus granulaus y Suillus luteus). El aislamiento y purificación de las cepas se hizo en medio de cultivo papa-dextrosa-agar (PDA), y la evaluación de la velocidad de crecimiento radial $(\mathrm{RG})$ y del incremento en biomasa micelial (MB), bajo diferentes condiciones de cultivo, se hizo en el medio de crecimiento Melin Norkrans Modificado (MMN). Los efectos de la temperatura $\left(24,28\right.$ y $\left.32{ }^{\circ} \mathrm{C}\right)$ y $\mathrm{pH}(4,8,5,3,5,8,6,3$ y 6,8$)$ del medio de crecimiento fueron probados para las tres especies fúngicas en dos ensayos independientes. Los resultados indican que la temperatura tuvo un efecto significativo en la tasa de crecimiento radial (RG) y en el ncremento de biomasa micelial (MB), en todas las especies fúngicas evaluadas. Los más altos valores de GR y MB fueron registrados en $R$. luteolus, y los valores más bajos fueron registrados en S. luteus. Rhizopogon luteolus presentó la mayor sensibilidad a los cambios de $\mathrm{pH}$ del medio de cultivo. En cambio, no existió un patrón en la respuesta de crecimiento de $S$. granulatus y $\mathrm{S}$. luteus bajo diferentes condiciones de $\mathrm{pH}$. Cuando se cultivaron in vitro, las tres especies de ECMF estudiadas presentaron en su crecimiento micelial las fases de adaptación, crecimiento exponencial, declinación y estacionaria. Las respuestas de crecimiento in vitro registradas en el presente estudio mostraron el gran potencial de $R$. luteolus para ser utilizado en futuros programas de micorrización controlada para la producción en vivero de árboles de Pinus radiata en Chile.

Palabras clave: Rhizopogon, Suillus, biomasa, cultivo puro, tasa de crecimiento radial.

\section{INTRODUCTION}

Around $95 \%$ of higher plants naturally establish mutualistic symbiotic relationships with mycorrhizal fungi whose external mycelium can explore up to 1000 times more soil than the roots (Brundrett et al., 1996; Honrubia et al., 1992). Therefore, this symbiosis improves the nutrition of the associated plants by mobilizing nutrients and water (Honrubia et al., 1992; Quoreshi, 2008; Skinner and Bowen, 1974). Quality of plants successfully mycorrhized by ectomycorrhizal fungi (ECMF) is improved in terms of vigor, drought tolerance, increase in nutrient uptake and resistance to post-transplant stress in the field (Bücking et al., 2012; Dulmer et al., 2014). The inoculation with ECMF is a recommended practice to produce plants of high quality in nurseries (Díaz et al., 2009).

The selection of the appropriate ectomycorrhizal fungal species as symbionts and their subsequent manipulation, both in the laboratory and in the nursery, can be a key factor for the successful establishment of many tree species in the field (Chávez et al., 2007; Honrubia et al., 1992; Marx et al., 1991). One criteria of great relevance in the selection of the ECMF is the use of species which 
are growing naturally associated with the selected plants in the sites of interest (Honrubia et al., 1992; Pereira et al., 2007). Different types of mycorrhizae have been described depending on the structures that they form, although in the case of tree species relevant in forestry in temperate climates, the ectomycorrhiza is the most important type of mycorrhizae (Harley and Smith, 1983; Marks and Kozlowski, 1973; Smith and Read, 2008).

The ECMF is an important component of microbial soil communities in boreal, temperate, mediterranean and some tropical forests, where they play an important role in nutrient recycling processes (Allen et al., 1995). In nature, ECMF growth depends on factors such as temperature, $\mathrm{pH}$, humidity, physical and chemical soil properties and nutrient availability, mainly carbon and nitrogen sources (Bowen, 1973; Harley and Smith, 1983). The ECMF are usually mesophilic; the temperature directly influences their growth because it affects the enzymatic production; and thus, can cause the denaturation of proteins and other macromolecules of the cell membranes (Frioni, 1999). Additionally, the soil $\mathrm{pH}$ affects the microbial activity through the solubility and the ionization of the inorganic and organic compounds in the soil solution (Voroney, 2007).

In vitro pure culture studies contribute to the study of the ECMF in order to understand their behavior in different cultivation conditions (Pirt, 1975). Growth differences of ECMF under in vitro conditions have been considered a guide for prescreening potential fungal species (strains or ecotypes) to be used in nursery mycorrhization programs. In the present study, the biomass production in different in vitro conditions was analyzed in order to understand the optimal temperature and $\mathrm{pH}$ conditions for the evaluated ECMF (Eng et al., 2003; Lazarević et al., 2016; Pereira et al., 2007; Sánchez et al., 2001). The objective of the present study was to analyze the effect of three temperatures and five different $\mathrm{pH}$ levels on the in vitro growth of the species of ECMF R. luteolus, S. granulatus and S. luteus naturally associated with Pinus radiata plantations growing at low productivity sites in Chile, assuming that each strain or ecotype has its own ecological optimal conditions.

\section{MATERIALS AND METHODS}

Fungal material. The ectomycorrhizal fungi (ECMF) Rhizopogon luteolus Fr., Suillus granulatus (L.) Roussel and Suillus luteus L. Gray were harvested in an adult plantation of Pinus radiata D. Don growing on a representative site of a large forest area with sandy soils of low productivity $(\mathrm{pH}$ 5.6; organic matter: $2.39 \%$; N:1.3 \%; P.6.7 \%; K:47.9 \%) in the province of Biobío, Region VIII, Chile (370 20'42.58 "S, $72^{\circ}$ 17'55.15 "W) during June to September 2015 (Figures 1A, $B, C)$. The species identification was performed by using a macro- and micro-morphological characterization of their sporomes (Calonge, 2009; Gerhardt et al., 2000; Honrubia et al., 2010; Lazo, 2016). In laboratory, under aseptic conditions in a laminar flow cabinet (ESCO ${ }^{\circledR}$, USA) the sporomes were dissected and small parts of the pilea context located immediately above the hymenium in epigeous mushrooms; and in the central area of the gleba in hypogeal fungi, were respectively extracted (Brundrett et al., 1996; Honrubia et al., 1995; Kumar y Satyanarayana, 2002).

The tissue fragments were placed in $50 \mathrm{~mm}$ diameter Petri dishes with $10 \mathrm{~mL}$ of potato-dextrose-agar medium (HiMedia®, India) with pH adjusted to 5.8. For each species, five strains were collected from the collection site, and from them, the strain with the best initial growth was studied in detail. The plates were incubated at $24 \pm 1{ }^{\circ} \mathrm{C}$ (BINDER ${ }^{\circledR}$ incubator, Germany) until an active growth of the mycelia (stock cultures) was obtained. Later, agarmycelial discs of $5 \mathrm{~mm}$ in diameter of the margin of the isolated strains (Díaz et al., 2009), were transferred to new Petri plates with $20 \mathrm{~mL}$ of potato-dextrose-agar medium and $\mathrm{pH}$ adjusted to 5.8 , in order to complete the processes of isolation and purification. These plates were incubated at $24 \pm 1{ }^{\circ} \mathrm{C}$ for $18 \mathrm{~d}$, obtaining pure strains of the three ECMF species of R. luteolus, $S$. granulatus, and S. luteus (Figures 1A, B, C).

Experimental approach. Two independent experiments were set up. In the first experiment, the effect of the temperature was evaluated. The three ECMF strains were cultivated at pH 5.8 and the effect of three different temperatures was evaluated. In the second experiment, the effect of $\mathrm{pH}$ on mycelial growth was evaluated for the three isolated strains. The strains were cultivated at $24{ }^{\circ} \mathrm{C}$ and the effect of five different $\mathrm{pH}$ values was evaluated.

Culture conditions tested. In the first experiment, the evaluated temperatures were 24,28 and $32^{\circ} \mathrm{C}$ (Andrino et al., 2011; Arana-Gabriel et al., 2014; Bran et al., 2015; Lazarević et al., 2016). From growing active colonies (stock cultures), $5 \mathrm{~mm}$ diameter agar-mycelial discs were transferred to $90 \mathrm{~mm}$ diameter Petri dishes containing $20 \mathrm{~mL}$ of agar Modified Melin Norkrans (MMN) as a culture medium, with a $\mathrm{pH}$ adjusted to 5.8. This $\mathrm{pH}$ value was used because it has been successfully employed in the cultivation of other ECMF. Five plates per species and three temperature values were set up $(n=45)$. Cultures were grown in three separate incubators (Memmert ${ }^{\circledR}$, Germany). In the second experiment, five different $\mathrm{pH}$ values were evaluated: 4.8, 5.3, 5.8, 6.3 and 6.8 (González et al., 2015; Pereira et al., 2007; Sundari and Adholeya, 2003; Vázquez-García et al., 2002). Prior to sterilization, the $\mathrm{pH}$ adjustment of the culture medium was performed with a PH 21 Hanna Instruments electrode by applying $\mathrm{HCl}$ to acidify the medium and $\mathrm{KOH}$ to basify 
A)

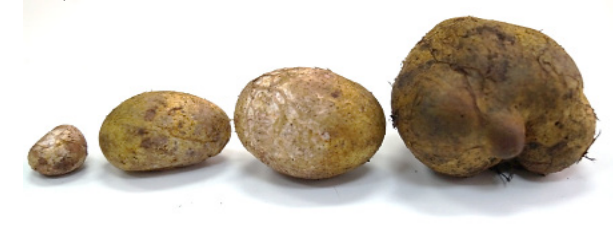

RI
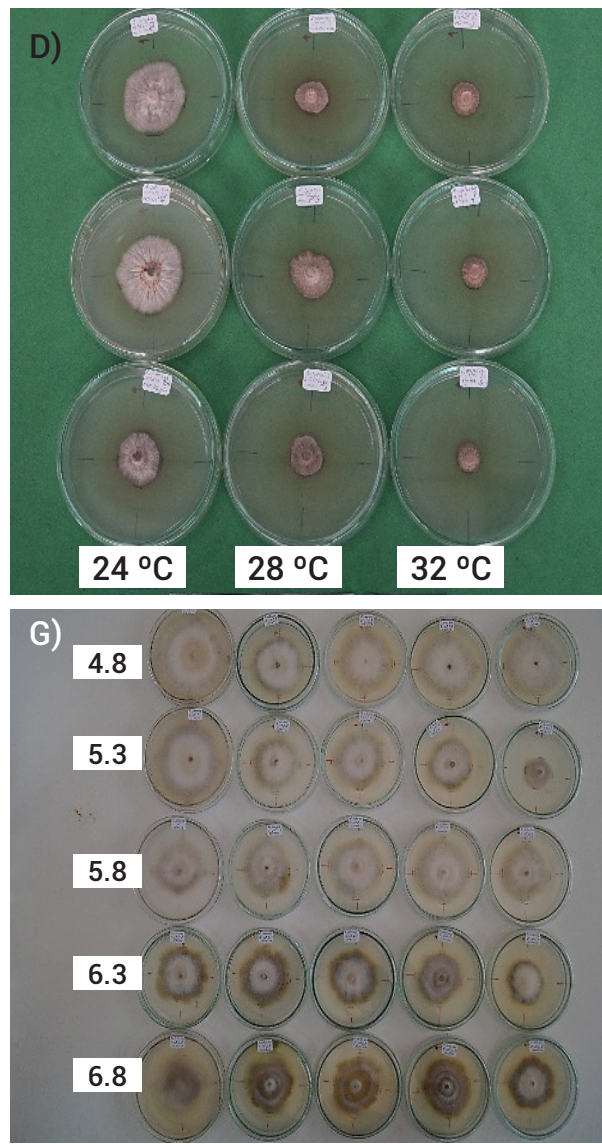

B)
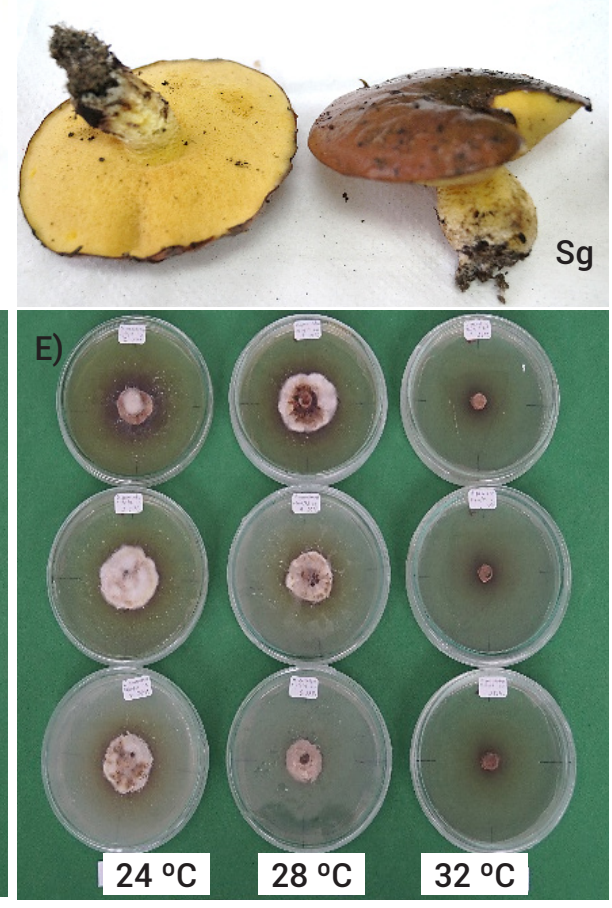

H) 4.8

5.3

5.8

6.3

6.8
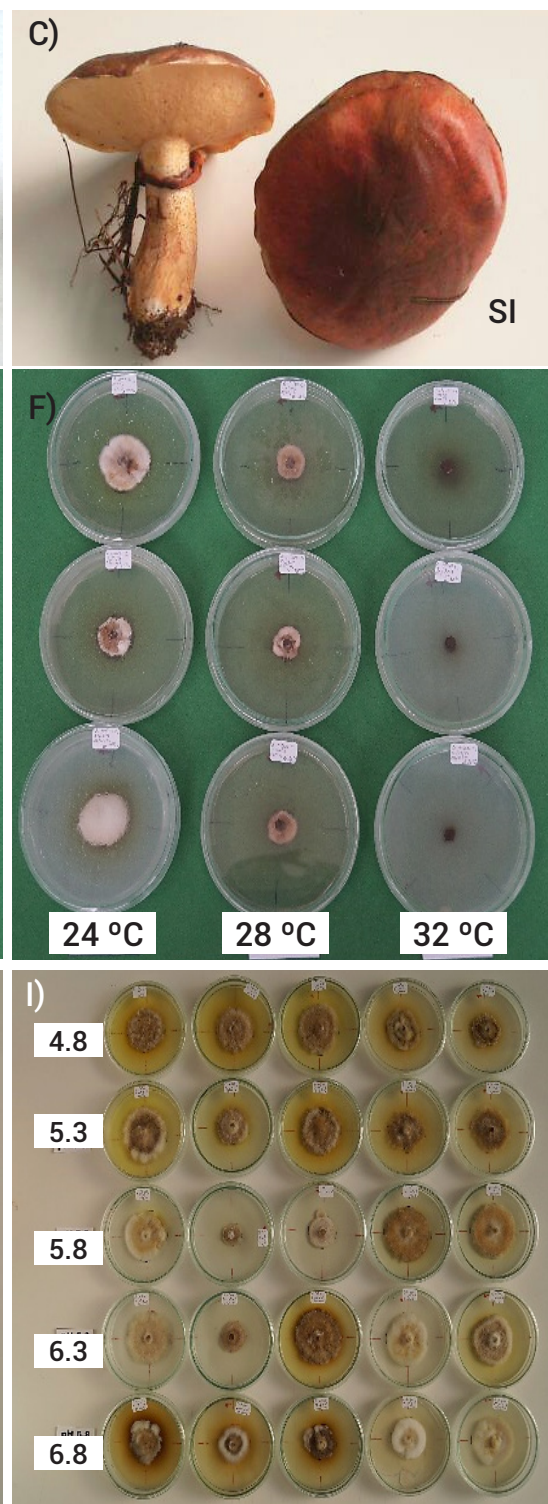

Figure 1. Sporomes of the ectomycorrhizal fungi Rhizopogon luteolus (A), Suillus granulatus (B), S. luteus (C) and in vitro mycelial growth at three temperatures $(D, E$ and $F)$ and five $\mathrm{pH}$ values $(\mathrm{G}, \mathrm{H}$ and I) in Modified Melin Norkrans culture medium.

it. In this experiment, $5 \mathrm{~mm}$ diameter agar-mycelial discs were transferred to $90 \mathrm{~mm}$ diameter Petri dishes containing $20 \mathrm{~mL}$ of agar MMN culture medium, with each level of $\mathrm{pH}$ tested. Five plates for each $\mathrm{pH}$ value were set up (n $=75$ ), which were incubated in darkness at $24 \pm 1^{\circ} \mathrm{C}$ based on the fact that this was the optimal temperature in terms of fungal growth in the first experiment.

Growth traits. The average radial growth $(R G)$ of the evaluated ECMF strains was recorded for each of the evaluated temperatures and $\mathrm{pH}$ values. The plates were incubated for $21 \mathrm{~d}$ and the radial growth of the colonies was measured every $3 \mathrm{~d}$ on the back of the plates (in four directions that passed through the center of the colonies) with a digital caliper (Mitutoyo, Mod. CD-6, Japan) (Murrieta-Hernández et al., 2014). The non-accumulated radial growth (NARG) was the average of the growth distance of four radial points for each measurement, to which the average growth of previous measurements was not added.

These data were adjusted by a linear regression equation to calculate the slope of the growth curve corresponding to the average growth rate of each fungal species and expressed in $\mathrm{mm} \mathrm{d}^{-1}$ (Santiago-Martínez et al., 1995; Vázquez- García et al., 2002). After the culture period, the increase in mycelial biomass (MB) was evaluated for both experiments by recovering the biomass produced in Petri dishes with vacuum filtration (Filtering Pump K, model SU 
660, Germany). The filtering of the growth medium previously melted in a microwave was carried out by using filter paper, previously oven dried and weighed in an analytical balance (RADWAG $\circledast$, USA). The mycelial mass retained on the filter paper was oven dried (Memmert, model BE-400, Germany) at $60{ }^{\circ} \mathrm{C}$ during $48 \mathrm{~h}$ in order to determine the constant dry weight (Duñabeitia et al., 2004; Pereira et al., 2014).

Statistical analysis. In every experiment, a completely randomly statistical designs with factorial arrangements, $3 \times 3$ in the first experiment and $3 \times 5$ in the second experiment, was used. In the first experiment the factors were: ECMF species and culture temperatures, giving a total of 45 experimental units. In the second experiment, the factors were the ECMF species and the $\mathrm{pH}$ of the culture medium, giving a total of 75 experimental units. In order to determine the effect of the studied factors on the RGR and $\mathrm{MB}$, the tests of homogeneity of variances and normality through the Shapiro-Wilk and Levene Test were previously performed. When the distributional assumptions were not verified, Box-Cox powers for data normalization (Olivier and Norberg, 2010) were applied. In both experiments a two-way analysis of variance was performed with a $95 \%$ confidence level and because the interaction was significant, contrasts were performed by LSD Fisher $(a=0.05)$ for the analysis of significant differences. Tukey $(P<0.05)$ mean comparison tests (Steel and Torrie, 1989) were carried out among treatments. Statistical analysis of the data was performed by using the statistical program STATGRAPHICS®.

\section{RESULTS}

\section{Experiment I (temperature)}

Radial growth (RG). The results showed that the temperature had a significant effect on the RG for the three ECMF evaluated species, with a negative effect when this variable increased (Figures 1D, E and F; Figure 2A). The highest RG was obtained at $24{ }^{\circ} \mathrm{C}$ and the lowest at $32{ }^{\circ} \mathrm{C}$, regardless of the ectomycorrhizal fungi (ECMF), having differences $(P<0.05)$ among species. It was observed that $R$. luteolus and $S$. luteus had greater sensitivity to the temperature change, expressed in the differences between their treatments $(P<0.05)$. Rhizopogon luteolus had the highest $R G$ in the three evaluated temperatures being $2.49,1.81,1.10$ $\mathrm{mm} \mathrm{d}^{-1}$, respectively. These $R G$ were different $(P<0.05)$ to those recorded for $S$. luteus and S. granulatus in the three evaluated temperatures. The last two species did not show differences $(P<0.05)$ in $R G$ between them, independently of the tested temperatures.

Mycelial biomass (MB). The MB of the three evaluated
ECMF was also affected by the tested temperatures (Figure $2 \mathrm{~B})$. The highest $(\mathrm{P}<0.05) \mathrm{MB}$ was registered at 24 ${ }^{\circ} \mathrm{C}$ and the lowest at $32{ }^{\circ} \mathrm{C}$ for all species. Rhizopogon luteolus showed the highest sensitivity, expressed as differences $(P<0.05)$ between each of the tested temperatures. Suillus granulatus and $\mathrm{S}$. luteus only showed differences $(\mathrm{P}<0.05)$ between extreme temperatures $\left(24\right.$ and $\left.32{ }^{\circ} \mathrm{C}\right)$. Rhizopogon luteolus had the highest MB with 143.5, 101.8 and $60.7 \mathrm{mg}$, and S. luteus had the lowest MB with 28.5, 17.3 and $1.9 \mathrm{mg}$ for the three evaluated temperatures, respectively. At the most extreme temperatures (28 and 32 $\left.{ }^{\circ} \mathrm{C}\right)$ there were greater MB differences $(\mathrm{P}<0.05)$ in the three ECMF.

\section{Experiment II $(\mathrm{pH})$}

Radial growth (RG). The $\mathrm{pH}$ had a different effect on the RG of the evaluated fungal species, and there was not a defined pattern (Figures 1G, H, I, and Figure 3A). Rhizopogon luteolus reached its maximum $(\mathrm{P}<0.05) \mathrm{RG}$ at $\mathrm{pH} 4.8(1.52$ $\left.\mathrm{mm} \mathrm{d}^{-1}\right)$ and the lowest at $\mathrm{pH} 6.3\left(1.00 \mathrm{~mm} \mathrm{~d}^{-1}\right)$, with significant differences between $\mathrm{pH} 4.8$ compared to $5.8,6.3$ and 6.8. This species showed the highest RG in all of the evaluated $\mathrm{pH}$ values compared with the other two fungal species. In the case of $S$. granulatus and $S$. luteus, the $R G$ only differed $(\mathrm{P}<0.05)$ at $\mathrm{pH} 4.8,5.3$ and 6.8.

Mycelial biomass (MB). Rhizopogon luteolus showed only MB differences $(\mathrm{P}<0.05)$ between the extreme $\mathrm{pH}$ treatments (4.8 and 6.8) (Figure 3B). Suillus granulatus and $S$. luteus did not show a pattern in terms of MB when grown in the different evaluated $\mathrm{pH}$ values. The $\mathrm{pH}$ of 4.8 yielded a higher $(P<0.05) \mathrm{MB}$ in $R$. luteolus $(104.76 \mathrm{mg})$ compared to S. granulatus (63.26 mg) and S. luteus (64.74 mg).

\section{Experiments I and II (temperature and $\mathrm{pH}$ )}

Accumulated radial growth (ARG) and non-accumulated radial growth (NARG). The three evaluated ECMF showed the four cultivation growth phases: culture medium adaptation, exponential, declining and stationary phases. In general, this trend was observed in all of the evaluated temperatures and $\mathrm{pH}$ values (Figures $4 \mathrm{~B}$ and $4 \mathrm{D}$ ). The adaptation phase was longer (approximately $6 \mathrm{~d}$ ) in the experiment where the influence of temperature was evaluated compared with that of different pH values (approximately $3 \mathrm{~d}$ ) (Figures $4 \mathrm{~A}$ and $4 \mathrm{C}$ ). Rhizopogon luteolus showed the highest ARG in both the temperature and $\mathrm{pH}$ experiments (Figures $4 \mathrm{~A}$ and $4 C)$.

In R. luteolus, the period of the exponential phase of NARG was dependent on the temperature. This phase concluded on day 12 at $24^{\circ} \mathrm{C}$ and on day 9 at both $28^{\circ} \mathrm{C}$ and $32{ }^{\circ} \mathrm{C}$ (Figure 4B). After this phase, the decline of NARG in 

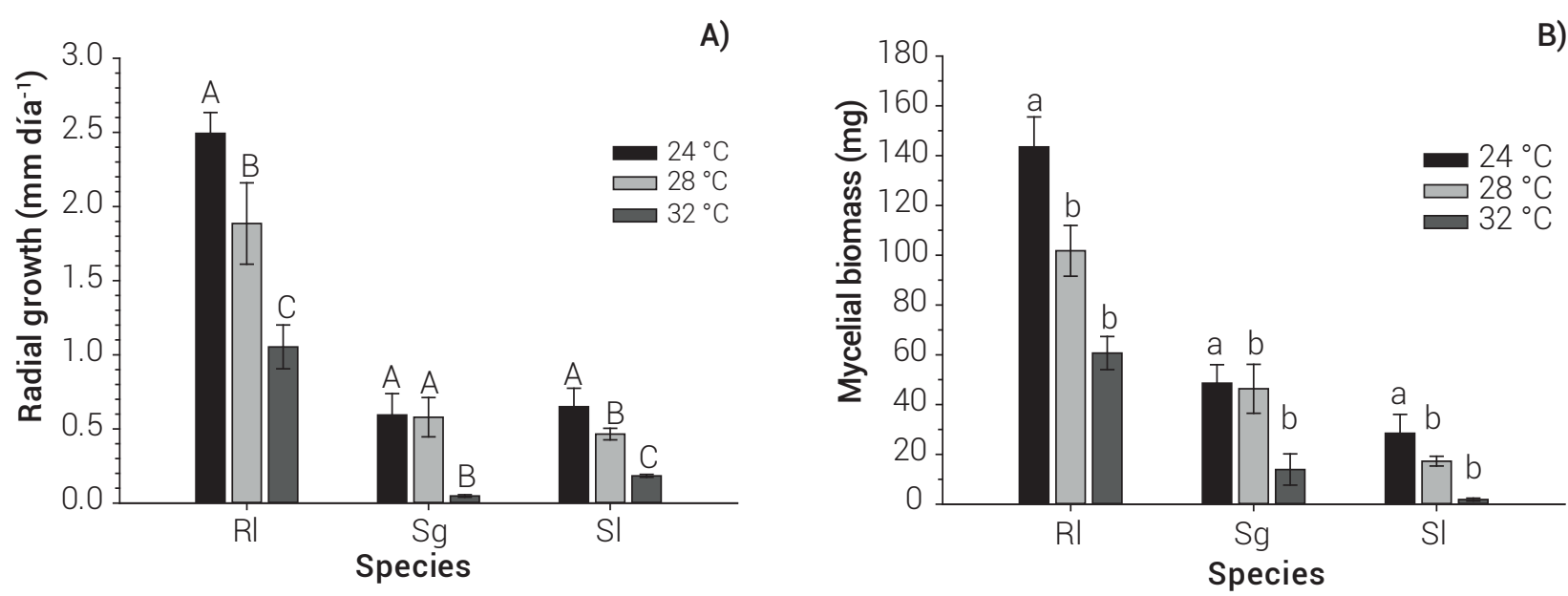

Figure 2. (A) Radial growth $\left(\mathrm{mm} \mathrm{d}^{-1}\right)$ and (B) mycelial biomass $(\mathrm{mg})$ of three fungal ectomycorrhizal species at three culture temperatures. Values are means \pm standard error of the mean $(n=5)$. Bars with the same letter, for each species, are not different according to the Tukey test $(\mathrm{P}<0.05)$. $\mathrm{Rl}=$ Rhizopogon luteolus; $\mathrm{Sg}=$ Suillus granulatus; $\mathrm{SI}=$ Suillus luteus .
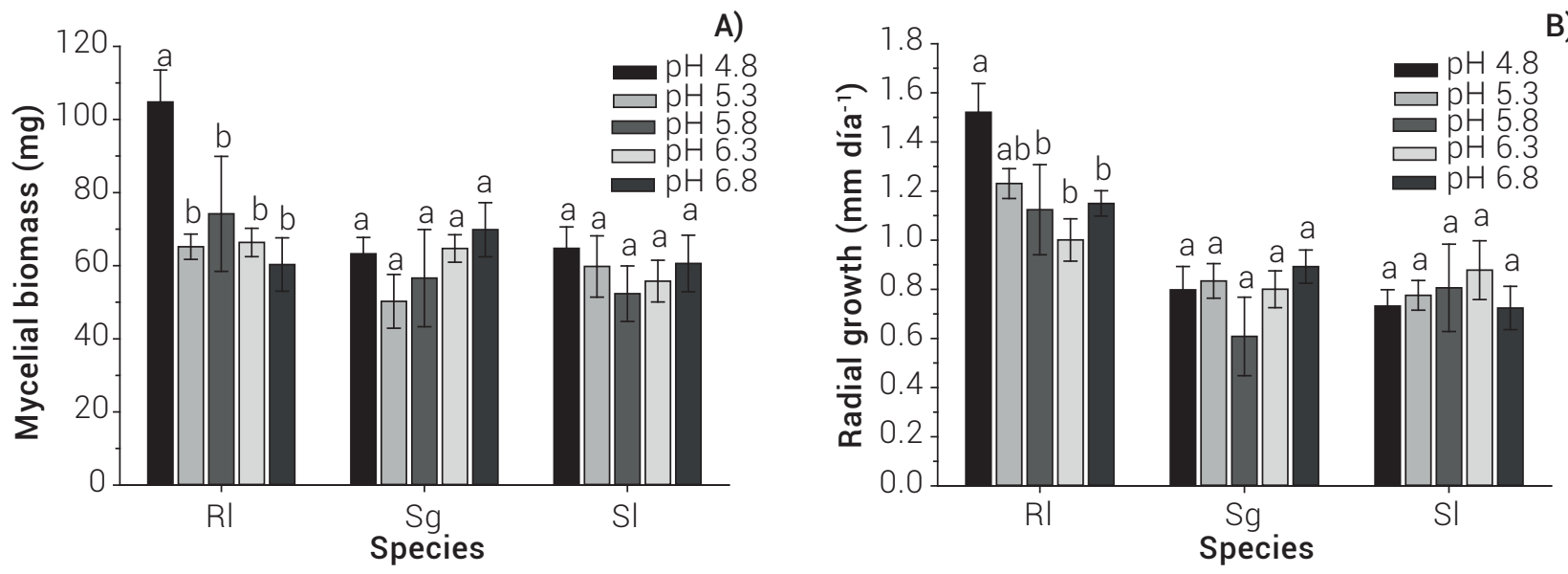

B)

Figure 3. (A) Radial growth $\left(\mathrm{mm} \mathrm{d}^{-1}\right)$ and (B) mycelial biomass $(\mathrm{mg})$ of three fungal ectomycorrhizal species at five $\mathrm{pH}$. Values are means \pm standard error of the mean $(n=5)$. Bars with the same letter, for each species, are not different according to the Tukey test $(\mathrm{P}<0.05)$. $\mathrm{RI}=$ Rhizopogon luteolus; $\mathrm{Sg}=$ Suillus granulatus; $\mathrm{SI}=$ Suillus luteus .

R. Iuteolus continued until day 21 , and then the stationary phase started. In the case of the experiment were different $\mathrm{pH}$ values were evaluated, in general the exponential phase of the NARG was shorter, finishing in between days 6 and 9 depending on the ECMF species. Then, the exponential period was recorded between days 15 and 18, and after that the declining phase began until day 24 , to conclude with the stationary phase of NARG (Figure 4D).

\section{DISCUSSION}

The knowledge of the biological, physiological and symbiotic characteristics of ECMF, as well as the specificity that they have with certain hosts, are fundamental requirements in order to choose the most appropriate fungal species in the production of ectomycorrhizal tree seed- lings. Environmental factors, including temperature and $\mathrm{pH}$, largely influence the formation and the development of mycorrhizal structures (Smith and Read, 2008). In general, most ECMF are considered to grow well at moderate temperatures between $11^{\circ} \mathrm{C}$ and $28^{\circ} \mathrm{C}$ (Hutchison, 1990). However, there are differences in the fungal growth among isolates of ECMF at different environmental temperatures (Dames et al., 1999; Hutchinson, 1990).

Some studies have shown that the ectomycorrhizal mycelium might be very sensitive to temperature variations (Lazarević et al., 2016; Marx et al., 1970; Sánchez et al., 2001). If the soil dramatically cools, the metabolic activity of the fungi and the roots decrease, with negative consequences for mycelial growth and nutrient availability for both the fungi and the associated plants (Lazarević et al., 

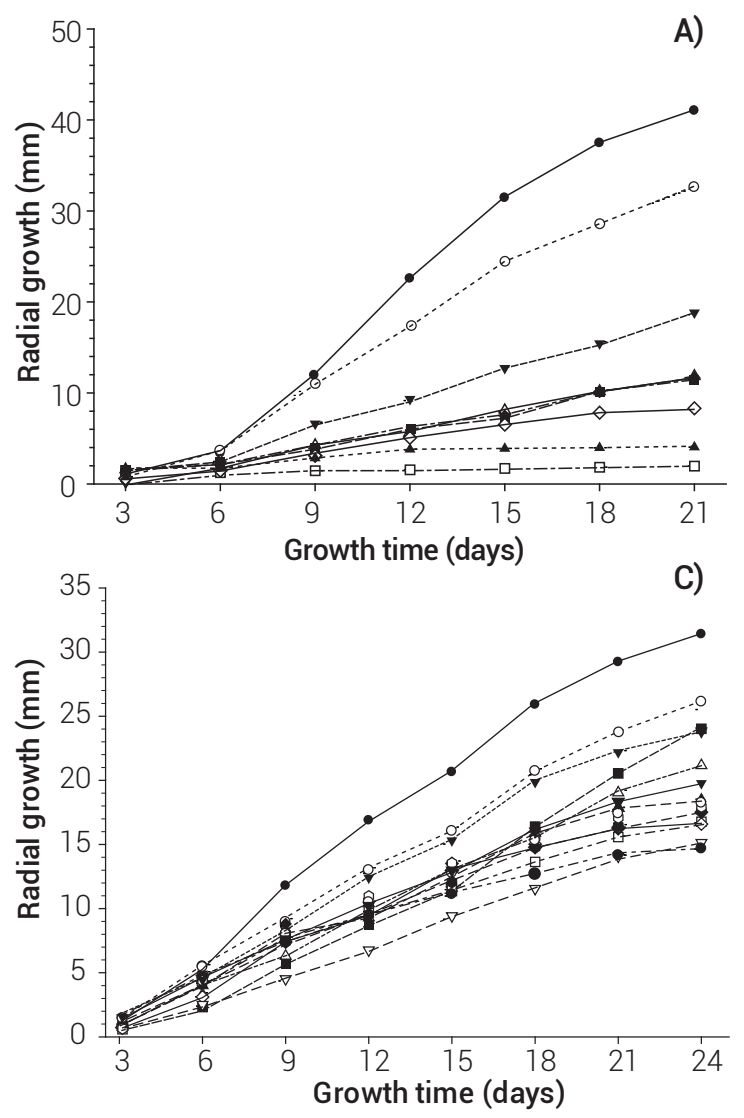

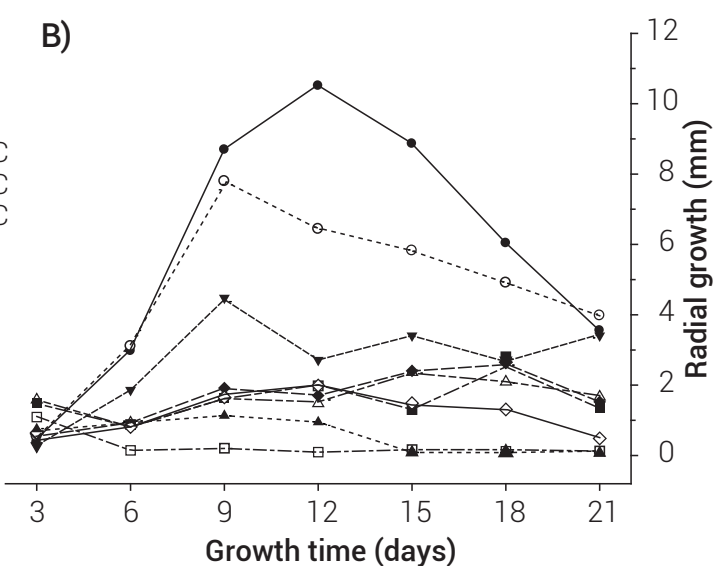

D)
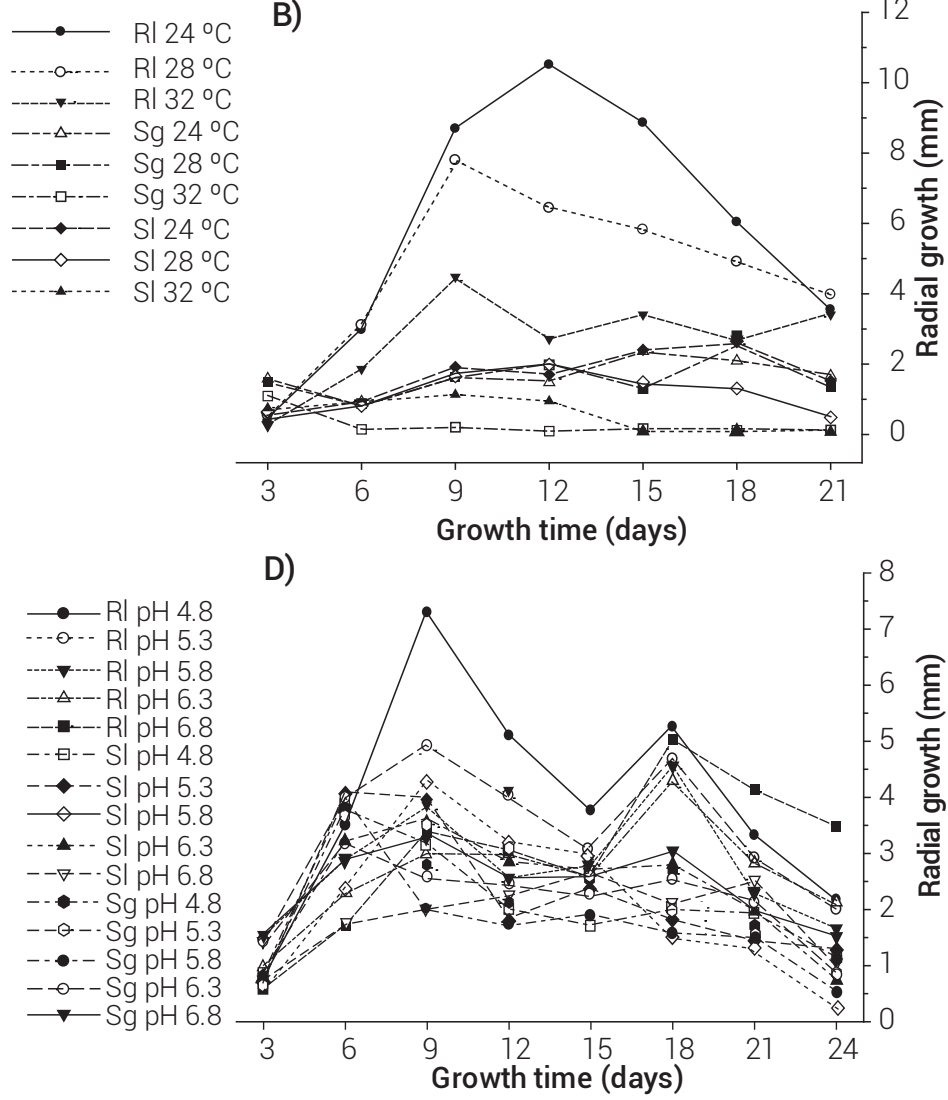

Figure 4. Average ( $A$ and $C$ ) accumulated and ( $B$ and $D$ ) non-accumulated radial growth of three fungal ectomycorrhizal species at three temperatures (at $\mathrm{pH} 5.8$ ) and under five $\mathrm{pH}$ values $\left(\right.$ at $\left.24^{\circ} \mathrm{C}\right)$. Values are means $(\mathrm{n}=5)$. In order to have more clarity in the graphs the \pm error bars are not shown. $\mathrm{RI}=$ Rhizopogon luteolus; $\mathrm{Sg}=$ Suillus granulatus; $\mathrm{SI}=\mathrm{Suillus}$ luteus.

2016). The results of the present study showed that the culture temperature had an effect on the in vitro growth of $R$. luteolus, S. granulatus and S. luteus species. The best growth, both in terms of $R G$ and $M B$, was reached at 24 ${ }^{\circ} \mathrm{C}$ for the three species in the evaluated ECMF, and when the temperature was increased to 28 and $32^{\circ} \mathrm{C}$, a negative effect was observed.

Different authors have reported similar findings to those that we found here. Jha et al. (2006) reported optimal growth for $R$. luteolus in temperatures ranging from 20 to $25^{\circ} \mathrm{C}$. Sánchez et al. (2001) recorded the highest growth values for $R$. roseolus, Suillus collinitus, S. granulatus and S. luteus at temperatures of $23^{\circ} \mathrm{C}$; similarly to our own findings, these authors registered significant decreases with increasing temperatures. Dennis (1985) reported optimal growth for S. granulatus at $25^{\circ} \mathrm{C}$ and for $\mathrm{S}$. luteus in the interval of 20 to $25^{\circ} \mathrm{C}$. Lazarević et al. (2016) recorded the best growth for S. collinitus and S. granulatus at $22^{\circ} \mathrm{C}$. Cline et al. (1987) reported the best growth for $S$. granulatus at $27^{\circ} \mathrm{C}$, and for Suillus spp. optimal mycelial growth between 16 and $32^{\circ} \mathrm{C}$.
In the present study, $R$. luteolus showed the best mycelial growth among the three studied ECMF species independently of the temperatures tested. Sánchez et al. (2001) found similar results for Rhizopogon and Suillus species. The maximum radial growth rate reached by $R$. luteolus $\left(2.49 \mathrm{~mm} \mathrm{~d}^{-1}\right)$ in the present work was above those previously reported $1.15,1.98$ and $1.28 \mathrm{~mm} \mathrm{~d}^{-1}$ by Chávez et al. (2007), Pereira et al. (2007) and Vázquez-García et al. (2002), respectively. However, the maximum values of RG obtained here by $S$. granulatus and S. luteus are below those registered by Santelices et al. (2012) for S. luteus, under the same culture conditions.

The $\mathrm{pH}$ can biologically determine the type of organism able to develop on a soil or a substrate, due to its significant influence on the nutrient availability (Pereira et al., 2007). The $\mathrm{pH}$ can strongly affect the microbial activity through nutrient availability, ionization of the constituents of the inorganic and organic soil solution, and therefore can have a paramount importance in the enzymatic activity of the soil (Voroney, 2007). In the present study, a different behavior of the evaluated ECMF species was recorded at the different 
$\mathrm{pH}$ values. Rhizopogon luteolus presented the greatest sensitivity of $R G$ and $M B$ to changes in $\mathrm{pH}$, showing a decrease in these variables when the $\mathrm{pH}$ was increased. Jha et al. (2006) and Pereira et al. (2007) found similar trends for $R$. luteolus. Vázquez-García et al. (2002) reported optimal growth for Rhizopogon sp. in BAF medium at pH 6.0, and significant growth decreases when $\mathrm{pH}$ was either increased or decreased. Duñabeitia et al. (2004) did not find changes in terms of colony diameter and mycelial growth biomass of $R$. luteolus when the $\mathrm{pH}$ was modified.

In the present study, S. granulatus and S. luteus did not show a clear trend when the $\mathrm{pH}$ changed. Similar responses were found for S. luteus by Santelices et al. (2012) and for S. bellinii by Pereira et al. (2007). In their studies with several species of Suillus, Murrieta-Hernández et al. (2014) and Vázquez-García et al. (2002) reported different behaviors in terms of growth when the $\mathrm{pH}$ of the culture medium was modified. In contrast, Dennis (1985) found significant differences in radial growth when $S$. granulatus and $\mathrm{S}$. luteus were grown in ranges of $\mathrm{pH}$ from 3 to 6 . Barros et al. (2006), and Pereira et al. (2007) recorded differences in terms of RG for $S$. luteus when the $\mathrm{pH}$ was modified. In our work, $R$. luteolus showed the highest values of RG at $\mathrm{pH} 4.8\left(152 \mathrm{~mm} \mathrm{~d}^{-1}\right)$ and at $\mathrm{pH} 6.3$ the lowest one $(1.0 \mathrm{~mm}$ $\left.\mathrm{d}^{-1}\right)$. The results showed that, in general, $R$. luteolus tends to grow better under acidic than alkaline conditions. This finding agrees with the trends mentioned by Hung and Trappe (1983), Lazarević et al. (2016) and Willenborg et al. (1990), who mentioned that ECMF have in general, an acidophilic nature when grown under pure culture conditions.

However, it is important to mention that there are some exceptions either specific or intraspecific, i.e. Sánchez et al. (2001) found that S. granulatus, S. luteus and S. collinitus had their best biomass increase responses at a $\mathrm{pH}$ of 8.5. In vitro mycelial growth of a fungus changes according to the culture medium used and the experimental culture conditions (Pereira et al., 2014; Santelices et al., 2012). The lack of significant trends obtained in the $\mathrm{pH}$ experiment could probably be explained because no biological buffers were added to growth media. Such buffers are essential to stabilize the $\mathrm{pH}$ variable. According to García-Rodríguez et al. (2006) and Hung and Trape (1983) during the development of in vitro mycelium, ECMF produce a series of organic acids, through the absorption of ions, acidifying the growth medium, and negatively affecting the growth and development of the fungi. Additionally, conventional culture media such as Modified Melin Norkrans have low buffering capacity and therefore the effects of $\mathrm{pH}$ on fungal growth in such media are difficult to evaluate (Child et al., 1973, Hung and Trappe, 1983; Yamanaka, 2003).

Organic and inorganic acids, such as acetates, citra- te, phthalate and phosphate, have been used as alternative buffers to stabilize pH. Guerin-Laguette et al. (2000) showed the importance of biological buffers in $\mathrm{pH}$ experiments with fungal growth, they found very strong evidence of the influence of $\mathrm{pH}$ on the in vitro mycelial development of two edible ectomycorrhizal mushrooms. The growth of Lactarius deliciosus and $L$. sanguifluus was optimal at $\mathrm{pH}$ 5.5-6.0 and 5.5-6.5, respectively. They used $5 X$ agar medium to which the biological buffer MES (2-( $N$-morpholino) ethanesulfonic acid was added and the $\mathrm{pH}$ was adjusted with $4 \mathrm{M} \mathrm{NaOH}$ prior to autoclaving. Although some of these acids may inhibit the growth of fungi (Giltrap and Lewis, 1981; Hilger et al., 1986; Inoue and Ichitani, 1990), MES and other buffers such as piperazine- $\mathrm{N}$ and N'-bis (2-ethanesulfonic acid) are considered to be physiologically inert (Good et al., 1966). It has also been shown that these buffers can stimulate the growth of some ectomycorrhizal fungi (Yamanaka, 2003).

The fungi present a growth kinetics that usually involves the adaptation, exponential, declining and stationary phases (Manero et al., 2012; Sánchez and Royse, 2002). The three species of evaluated ECMF in the present work showed these four well-defined phases in our in vitro culture conditions. It was observed that the adaptation phase was more conspicuously marked in the first experiment where temperatures were evaluated, compared to the second experiment where the effect of $\mathrm{pH}$ conditions was studied. Santelices et al. (2012) reported only the adaptation, exponential and stationary phases for S. luteus. Coleman et al. (1989) reported the same growth pattern for S. Iuteus in Modified Melin Norkrans culture medium, with absence of the initial adaptation phase; however, when water stress treatments were involved in their trials, the initial phase of adaptation became more conspicuous.

In our study the exponential phase of $R$. luteolus was strongly dependent on the culture temperature. When the $\mathrm{pH}$ of the medium varied, the period of the exponential phase was in general short, producing in some species a second period of exponential growth. In the kinetics study of the ECMF, the growth phases involved in their cultivation are fundamental to analyze and understand because they provide important information related to the particular growth dynamics of each ECMF species. These studies can show the exact moment when the mycelium of a particular fungus is physiologically active in culture, and has the maximum potential to be used as an inoculum in possible programs of inoculum production in order to produce mycorrhizal plants. The understanding of the optimal in vitro conditions to grow native strains will allow the generation of ectomycorrhizal inoculum in enough quantities to be applied to $P$. radiata tree production under greenhouse conditions. Such work has previously been carried 
out in other pine species such as P. pinea in Spain with Rhizopogon spp. (Rincón et al., 2005). Afterwards, if there is successful and abundant ectomycorrhizal colonization the establishment of plantations with the local plant and the studied fungal genotypes might be favoured.

\section{CONCLUSIONS}

The results indicated that the mean radial growth rate and the biomass increase of strains of R. luteolus, S. granulatus and S. luteus were significantly affected by increasing the temperature. The optimum cultivation temperature for all of the evaluated species was $24^{\circ} \mathrm{C}$. There was a significant decrease with temperature increases.

Under the present culture conditions without biological buffers, the $\mathrm{pH}$ variability of the medium, in the range of 4.8 to 6.8 , did not significantly affect the mycelial growth of $S$. granulatus and $S$. luteus species. However, R. luteolus decreased its growth when $\mathrm{pH}$ was increased.

Among the three evaluated fungal species, $R$. luteolus showed the greatest mycelial production. This species also shows the greatest potential for the large-scale production of mycelial inoculum at a larger scale, useful in the production of ectomycorrhizal Pinus radiata trees.

\section{ACKNOWLEDGMENTS}

The support of the National Institute of Forestry, Agriculture and Livestock Research of México (INIFAP, CORECADE NC13/83), of The Council National of Science and Technology of México (CONACYT 172007), and of The Chilean National Council for Science and Technology (CONICYT 2115253) through a doctoral scholarship granted to J. L. García-Rodríguez is acknowledged. The authors also thank two anonymous referees and the Editor whose valuable comments helped to substantially improve the original manuscript.

\section{BIBLIOGRAPHY}

Allen E. B., M. F. Allen, D. J. Helm, J. M. Trappe, R. Molina and E. Rincon (1995) Patterns and regulation of mycorrhizal plant and fungal diversity. Plant and Soil 170:47-62, http://dx.doi.org/10.1007/ bf02183054.

Andrino A., M. A. Morte G. y M. Honrubia G. (2011) Caracterización y cultivo de tres cepas de Pleurotus eryngii (Fries) Quélet sobre sustratos basados en residuos agroalimentarios. Anales de Biología 33:53-66, http://dx.doi.org/10201/27369.

Arana-Gabriel Y., C. Burrola-Aguilar, R. Garibay-Orijel y S. Franco-Maass (2014) Obtención de cepas y producción de inóculo de cinco especies de hongos silvestres comestibles de alta montaña en el centro de México. Revista Chapingo Serie Ciencias Forestales y del Ambiente 20:213-226, http://dx.doi.org/10.5154/r. rchscfa.2014.04.017.

Barros L., P. Baptista and I. C. F. R. Ferreira (2006) Influence of the culture medium and $\mathrm{pH}$ on the growth of saprobic and ectomycorrhi- zal mushroom mycelia. Minerva Biotecnologica 18:165-170, http://dx.doi.org/10198/824.

Bowen G. D. (1973) Mineral nutrition of ectomicorrhizae: In: Ectomycorrhiza, Their Ecology and Physiology. G. C. Marx and T. T. Kozlowsky (eds.). Academic Press. London Great, Britain. pp:151205

Bran M. C., R. Cáceres, N. Gurriarán, O. Morales y R. Flores (2015) Caracterización in vitro y producción de inóculo de cepas guatemaltecas de Lepista nuda (Bull.: Fr.) Cooke. Ciencia, Tecnología y Salud 2:5-13.

Brundrett M., N. Bougher, B. Dell, T. Grove and N. Malajczuk (1996) Working with Mycorrhizas in Forestry and Agriculture. ACIAR. Canberra, Australia. $373 \mathrm{p}$.

Bücking H., E. Liepold and P. Ambilwade (2012) The role of the mycorrhizal symbiosis in nutrient uptake of plants and the regulatory mechanisms underlying these transport processes. In: Plant Science. N. Kumar Dhal and S. Charan Sahu (eds.). InTech. pp:107-138, http://dx.doi.org/10.5772/52570

Calonge F. D. (2009) Guía de Bolsillo para el Buscador de Setas. Ediciones Mundi-Prensa. Madrid.158 p.

Chávez D., G. Pereira y A. Machuca (2007) Crecimiento in vitro de cuatro especies de hongos ectomicorrícicos recolectados en plantaciones de Pinus radiata. Agrociencia 23:79-84.

Child J. J., C. Knapp and D. E. Eveleigh (1973) Improved pH control of fungal culture media. Mycologia 65:1078-1086, http://dx.doi. org/10.2307/3758289

Cline M. L., R. R. C. France and C. P. P. Reid (1987) Intraspecific and interspecific growth variation of ectomycorrhizal fungi at different temperatures. Canadian Journal of Botany 65:869-875, http:// dx.doi.org/10.1139/b87-119.

Coleman M. D., C. S. Bledsoe and W. Lopushinsky (1989) Pure culture response of ectomycorrhizal fungi to imposed water stress. Canadian Journal of Botany 67:29-39, http://dx.doi.org/10.1139/ b89-005.

Dames J.F., C. J. Starker and M. C. Sholes (1999) Ecological and anatomical characterization of some Pinus patula ectomycorrhizas from Mpumalanga, South Africa. Mycorrhiza 9:9-24, http:// dx.doi.org/10.1007/s005720050258.

Dennis J. J. (1985) Effect of $\mathrm{pH}$ and temperature on in vitro growth of ectomycorrhizal fungi. Information Report BC-X-273. Pacific Forestry Centre. Canadian Forestry Service. $19 \mathrm{p}$.

Díaz G., R. Flores y M. Honrubia G. (2009) Descripción de cultivos miceliares de Boletales neotropicales y europeos (Boletus grupo edulis, Boletellus y Suillus) y formación de primordios de B. edulis en cultivo puro. Revista Mexicana de Micologia 30:1-7.

Dulmer K. M., S. D. LeDuc and T. R. Horton (2014) Ectomycorrhizal inoculum potential of northeastern US forest soils for American chestnut restoration: results from field and laboratory bioassays. Mycorrhiza 24:65-74, http://dx.doi.org/10.1007/s00572-013-0514-y.

Duñabeitia M. K., S. Hormilla, J. I. Garcia-Plazaola, K. Txarterina, U. Arteche and J. M. Becerril (2004) Differential responses of three fungal species to environmental factors and their role in the mycorrhization of Pinus radiata D. Don. Mycorrhiza 14:11-18, http:// dx.doi.org/10.1007/s00572-003-0270-5.

Eng F., M. Gutiérrez-Rojas y E. Favela-Torres (2003) Efecto de la temperatura y el pH en el crecimiento superficial de Botryodiplodia theobromae RC1. Revista Iberoamericana de Micología 20:172-175.

Frioni L. (1999) Estrategias nutritivas y bionergéticas en los microorganismos. Efecto del ambiente. In: Procesos Microbianos. L. Frioni (ed.). Editorial de la Fundación Universidad Nacional de Río Cuarto. Argentina. pp:2-14.

García-Rodríguez J. L., J. Pérez-Moreno, A. Aldrete, V. Cetina-Alcalá y H. Vaquera-Huerta (2006) Caracterización del hongo silvestre ectomicorrícico Pisolithus tinctorius (Pers.) Coke et Couch en cultivo y en simbiosis con eucalipto y pino. Agrociencia 40:665-676.

Guerin-Laguette A., C. Plassard and D. Mousain (2000) Effects of experimental conditions on mycorrhizal relationships between Pinus sylvestris and Lactarius deliciosus and unprecedented fruitbody formation of the saffron milk cap under controlled soilless conditions. Canadian Journal of Microbiology 46:790-799.

Gerhardt E., J. Vila y X. Llimona (2000) Hongos de España y de Europa. Barcelona, España. Omega. 957 p. 
Giltrap N. J. and D. H. Lewis (1981) Inhibition of growth of ectomycorrhizal fungi in culture by phosphate. New Phytologist 87:669-675, http://dx.doi.org/10.1111/j.1469-8137.1981.tb01701.x

Good N. E., G. D. Winget, W. Winter, T. N. Connolly, S. Izawa and R. M. M. Singh (1966) Hydrogen ion buffers for biological research. Biochemis try 5:467-477, http://dx.doi.org/10.1021/bi00866a011.

González M., I. Quiroz, R. Travieso, P. Chung y E. García (2015) Determinación de medios de cultivo y pH para la masificación in vitro de cepas de Suillus luteus Aubl. asociadas a Pinus radiata D. Don y Scleroderma citrinum Pers. asociadas a Eucalyptus globulus Labill. de la región del Biobío, Chile. Revista Árvore. 39:105-113, http://dx.doi.org/10.1590/0100-67622015000100010.

Harley J. L. and S. E. Smith (1983) Mycorrhizal Simbiosis. Academic Press. London, Great Britain. 483 p.

Hilger A. B., K. I. Thomas and H. H. Krause (1986) The effects of several buffers on growth and phosphorus nutrition of selected ectomycorrhizal fungi. Soil Biology and Biochemistry 18:61-67, https://doi.org/10.1016/0038-0717(86)90104-5

Honrubia M., P. Torres, G. Díaz y A. Cano (1992) proyecto LUCDEME. Manual para Micorrizar Plantas en Viveros Forestales. Instituto Nacional para la Conservación de la Naturaleza. Madrid, Espaก̃a. $47 \mathrm{p}$

Honrubia M., P. Torres, G. Díaz y A. Morte (1995) Biotecnología Forestal: Técnicas de Micorrización y Micropropagación de Plantas. Murcia, España. 84 p.

Honrubia M., V. Figueroa, J. Fajardo, A.Verde, D. Blanco y F. Sánchez (2010) Guía de Hongos Micodes. MICODES (Micología, Conservación y Desarrollo). Murcia, España. 281 p.

Hung L. L. and J. M. Trappe (1983) Growth variation between and within species of ectomycorrhizal fungi in response to $\mathrm{pH}$ in vitro. Mycologia 75:234-241, http://dx.doi.org/10.2307/3792807.

Hutchison L. J. (1990) Studies on the systematics of ectomycorrhizal fungi in axenic culture. II. The enzimatic degradation of selected carbon and nitrogen compounds. Canadian Journal of Botany 68:1522-1530, http://dx.doi.org/10.1139/b90-194

Inoue $\mathrm{M}$. and T. Ichitani (1990) Optimum $\mathrm{pH}$ range for mycelial growth of Pythium spp. estimated by MES [2-(N-morpholino) ethanesulfonic acid] buffer. Transactions of the Mycological Society of Japan 31:191-196.

Jha B. N., G. D. Sharma and A. K. Shukla (2006) Growth behaviour ectomycorrhizal fungi with different physical factors in vitro conditions. Asian Journal of Microbiology, Biotechnology and Environmental Sciences 8:339-343.

Kumar S. and T. Satyanarayana (2002) Isolation of ectomycorrhizal fungi: methods and techniques. In: Techniques in Mycorrhizal Studies. K. G. Mukerji, C. Manoharachary and B. P. Chamola (eds.) Springer. Dordrecht, Netherlands. pp:133-142

Lazarević J., D. Stojičić and N. Keča (2016) Effects of temperature, pH and carbon and nitrogen sources on growth of in vitro cultures of ectomycorrhizal isolates from Pinus heldreichii forest. Forest Systems 25:1-10, http://dx.doi.org/10.5424/fs/201625107036.

Lazo W. (2016) Hongos de Chile. Atlas Micológico. Segunda edición. Universidad de Chile, Departamento de Ciencias Ecológicas. Santiago, Chile. $316 \mathrm{p}$.

Manero C. I. N., M. de L. Acosta-Urdapilleta, E. Montiel A. y F. A. MedranoVega (2012) Otros hongos comestibles. Cultivo de Lentinula edodes en aserrín de jacarandas con nutrientes In: Hongos Comestibles y Medicinales en Iberoamérica. J. E. Sánchez V. y G. Mata (eds.). Colegio de la Frontera Sur. Tapachula, Chiapas, México. pp:229-239

Marks G. C. and T. T. Kozlowski (1973) Ectomycorrhizae: Their Ecology and Physiology. Academic Press. New York \& London. 444 p.

Marx D. H., J. L. Ruehle and C. E. Cordell (1991) Methods for studying nursery and field response of trees to specific ectomycorrhiza. In: Methods in Microbiology. Techniques for the Study Mycorrhiza. J. R. Norris, D. Read and A. K. Varma (eds.). Academic Press. London UK. pp:383-411.

Marx D. H., W. C. Bryan and C. B. Davey (1970) Influence of temperature on aseptic synthesis of ectomycorrhizae by Thelephora terrestris and Pisolithus tinctorius on loblolly pine. Forest Scien- ce16:424-431

Murrieta-Hernández D. M., J. C. Noa-Carrazana, M. Mata-Rosas, M. del R. Pineda-López, R. Zulueta-Rodríguez y N. Flores-Estévez (2014) Efecto del medio de cultivo en el desarrollo de Suillus granulatus (L.) Roussel y S. brevipes (Pk.) Kuntze. Revista Chapingo. Serie Ciencias Forestales y del Ambiente 20:101-107, http://dx.doi. org/10.5154/r.rchscfa.2013.06.021

Olivier J. and M. M. Norberg (2010) Positively skewed data: Revisiting the Box-Cox power transformation. International Journal of Psychological Research (Medellin) 3:68-77, http://dx.doi org/10.21500/20112084.846.

Pereira G., J. Herrera, A. Machuca y M. Sánchez (2007) Efecto del pH sobre el crecimiento in vitro de hongos ectomicorrícicos recolectados de plantaciones de Pinus radiata. Bosque 28:215-219, http:// dx.doi.org/10.4067/S0717-92002007000300005.

Pereira G., J. L. Campos, D. Chávez, L. Anabalón y C. Arriagada (2014) Caracterización del crecimiento miceliar del hongo ectomicorrícico Lactarius aff deliciosus y su simbiosis con plántulas de Pinus radiata. Quebracho 22:30-39.

Pirt S. J. (1975) Principles of Microbe and Cell Cultivation. Wiley. New York, USA. $274 \mathrm{p}$.

Quoreshi A. M. (2008) The use of mycorrhizal biotechnology in restoration of disturbed ecosystem. In: Mycorrhizae: Sustainable Agriculture and Forestry. Z. A. Siddiqui, M. S. Akhtar and K. Futai (eds.). Springer Netherlands. Dordrecht, Netherlands. pp:303320

Rincón A., J. Parladé and J. Pera (2005) Effects of ectomycorrhizal inoculation and the type of substrate on mycorrhization, growth and nutrition of containerized Pinus pinea $\mathrm{L}$. seedlings produced in a commercial nursery. Annals of Forest Science 62:817-822.

Sánchez F. M. Honrubia and P. Torres (2001) Effects of pH, water stress and temperature on in vitro cultures of ectomycorrhizal fungi from Mediterranean forests. Cryptogamie Mycologie 22:243 258

Sánchez J. E. y D. J. Royse (2002) La Biología y el Cultivo de Pleurotus spp. El Colegio de la Frontera Sur y LIMUSA. México. 294 p.

Santelices R., S. Espinoza, N. Brunel and G. Palfner (2012) Effect of the geographical origin, culture media, and $\mathrm{pH}$ on the growth dynamic of the edible ectomycohrrizal mushroom Suillus luteus. Ciencia e Investigación Agraria 39:369-376, http://dx.doi.org/10.4067/ S0718-16202012000200013.

Santiago-Martínez G., L.Varela, A. Estrada-Torres y V. Cuaxilo (1995) Efecto de seis medios de cultivo sobre el crecimiento de tres cepas de Pisolithus tinctorius. Revista Mexicana de Micología 11:57-68.

Skinner M. F. and D. G. Bowen (1974) The uptake and translocation of phosphate by mycelial strands of pine mycorrhizas. Soil Biology and Biochemistry 6:53-56, http://dx.doi.org/10.1016/00380717(74)90011-X

Smith S. E. and D. Read (2008) Mycorrhizal Simbiosis. Third Edition. Academic Press. Elsevier. Great Britain. 800 p.

Steel R. G. D. and J. H. Torrie (1989) Bioestadística: Principios y Procedimientos. Segunda Edición. McGraw Hill. México DF, México. $662 \mathrm{p}$

Sundari S. K. and A. Adholeya (2003) Growth profile of ectomycorrhizal fungal mycelium: emphasis on substrate $\mathrm{pH}$ influence. Antonie van Leeuwenhoek 83:209-214.

Vázquez-García A., G. Santiago-Martínez y A. Estrada-Torres (2002) Influencia del $\mathrm{pH}$ en el crecimiento de quince cepas de hongos ectomicorrizógenos. Anales del Instituto de Biología. Serie Botánica 73:1-15.

Voroney R. P. (2007) The soil habitat. In: Soil Microbiology. Ecology and Biochemestry. E. A. Paul (ed.). Third edition. Academic Press, Elsevier. Canada. pp:25-49.

Willenborg A., D. Schmitz and J. Lelley (1990) Effects of environmental stress factors on ectomycorrhizal fungi in vitro. Canadian Journal of Botany 68:1741-1746, http://dx.doi.org/10.1139/ b90-224.

Yamanaka T. (2003) The effect of pH on the growth of saprotrophic and ectomycorrhizal ammonia fungi in vitro. Mycologia 95:584-589, http://dx.doi.org/10.1080/15572536.2004.11833062. 
